\title{
Access and Management of Electronic Information Resources in Umaru Musa Yar'adua University Library, Katsina State Nigeria
}

\author{
Mohammed Tukur Lawal', Nafi'u Maharazu ${ }^{2}$ \\ ${ }^{1}$ Research Scholar, Department of Library and Information Science SRM University, Sonepat, Haryana, India \\ ${ }^{2}$ Assistant Lecturer Department of Library and Information Science
}

\begin{abstract}
The study investigated the access and management of electronic information resources in Umaru Musa Yar'adua University Katsina, library. The study adopted quantitative approach as research paradigm; with survey as research methods. Questionnaire was used as the primary instrument for data collection in which the entire forty two library staff was used as population of the study. The response rate of $92.9 \%$ was obtained, used and analyzed the data. From the findings of the study therefore, the influence of demographic variables (gender, age, education and professions) about the management of electronic information resources was not significant at the surveyed university library. Thus, the study recommended increased investment in ICT facilities, staff training and development at the surveyed university library to promote increase in the management of electronic information resources to satisfy the needs of users as ultimate goal of any library and information center.
\end{abstract}

KEY WORDS: Availability, Accessibility, electronic resources, information technology, ICT skills, IL skills, library staff

\section{INTRODUCTION}

A library is a collection of sources of information and similar resources, made accessible to a defined community for reference or borrowing. It provides physical or digital access to material, and may be a physical building or room, or a virtual space, or both. According to Okoye, M. \&Ezeani (2009). opined that electronic resources include CD-ROMs, e-books, e-journal, digital collections, databases and websites. Therefore, electronic information resources (EIRs) should be identifies, select, acquire, catalogue and maintain them by library staff for easy accessibility to users. According to (Breivold, 2009) stated that electronic resource management as the practices used by librarians to keep track of important information about electronic information resources, especially internet based resources such as electronic Journals, databases, and electronic books. Management of electronic information resources is the practices and software systems used by libraries to keep track of important information about electronic information resources, especially internet-based resources such as electronic journals, databases, and electronic books. The UMYU library has a number of CD-ROM collections and subscribes to some online databases such as Science direct, OARE, JSTOR, AGORA, HINARI and EBSCOHOST

This research therefore intended to assess the management of electronic information resources (EIRs) of UMYUK Library.

\section{Statement of the Problem}

An Academic library is expected to properly manage and provide relevant, accurate and up to date information resources both traditional and electronic information in order to satisfy the needs of the users, these resources can only be used and accessed when they are managed. Meanwhile, Based on the researcher's preliminary survey, the electronic information resources in Umaru Musa Yar'Adua University library are not effectively managed due to Poor storage environment, inadequate electricity power supply, technical problem, inadequate qualified staff, network problem and lack of awareness about the existence of the e-resources are the major problems affecting the management of electronic information resources in the library. This study therefore intends to study the access and management of electronic information resources at UMYUK library and figure out the solutions to the identified problems.

\section{Objectives of the Study}

The purpose of this research is to study the access and management of electronic information resources in Umaru Musa Yar'adua University Library Katsina State Nigeria. The specific objectives are to:

1. Identify the types of electronic information resources available in the UMYUK library.

2. Identify the strategies for enhancing the management of electronic information resources

3. Ascertain the IT-related problems that affect the management of electronic information

4. Ascertain the problems of staffing that affect the management of electronic information 


\section{REVIEW LITERATURE}

Okiki \& Asiru, (2011), Thanuskodi, (2012). opined that electronic resources as those resources which include documents in electronic formats that can be accessed via internet in a digital library environment as information stored and transmitted in digital, electronic or computerized formats such as diskettes, CD-ROM, databases, DVDs, online public access catalogues (OPAC), bibliographic and full-text databases, MEDLINE, electronic journals, scholarly databases, information gateways, e-books, internet and electronic mails. online journal, e-magazine, e-learning tutors, e-discussions, e-news, data archives and e-mail online chatting and deliver a collection of data, be it text, image collection, other multimedia products like numerical and / or graphical mode. Electronic resources include e-text or electronic books, locally loaded databases, websites and abstracting and indexing databases

According to Shuling (2007), electronic information has gradually become a major resource in every university library. The emergence of electronic information resources, simply referred to as electronic resources, has tremendously transformed information handling and management in academic environments and in University libraries in particular.

\section{Availability of Electronic Information Resources}

Availability of information resources refers to the presence of books and non-book materials in a library and provides the opportunity to access a wide range of topics on different subjects. E-resources are available in various forms like ebooks, digital libraries, online journal, magazine, e-learning tutors, e-discussions, e-news, data archives and e-mail online charting and deliver a collection of data, be it text, image collection, other multimedia products like numerical, graphical mode Akinsola, Tella, \& Tella, (2007) Ani \& Blessing (2008) revealed the high level of developing electronic information resources in University libraries through direct subscription and usage of internet resources but the ability to find and retrieve information effectively can be considered as a transferable skill which is useful for future life and to

\section{Management of Electronic Information Resources}

Management of electronic resources often refers to the tools and processes used to organize administrative metadata, such as license terms, vendor contracts and usage statistics. Jeyapragash, A.Muthuraj, \& Rajkumar, (2017) pointed out that ERMs help libraries to keep track of their online subscriptions and license agreements. They will equally enable libraries to view all information related to a particular resource without having to consult multiple files and spreadsheets.

In managing electronic information resources therefore, issue like digital preservation is very essential. Thus, preserving electronic or digital information resources refers to a method for ensuring ongoing access to digital objects or resources. It involves keeping the old technology, that is, hardware and software that were used to create and access the digital information in their original form and environment. Gbaje (2012) posited that digital preservation as a method for keeping stored digital objects permanently accessible for long-term use. While Adegbore, Okwilagwe, \& Salaam, (2013), have the viewed that management of electronic resources demands expertise in handling systems which are more complex than library management systems (LMS). It requires setting priorities on staff times, deciding how and who presides over the functionality of all things electronic, such as A-Z lists, federated search engines, e-journals, abstracting and indexing databases, dark archives, and ERMs (Electronic Resource Management Systems). It also involves providing the library users with convenient ways to find and access them and providing library staff with the tools to keep track of them.

\section{Staff Related Problems in the Management of Electronic Information Resources}

Library staffs are those personnel who are charged with the responsibility of identifying, selecting, acquiring, processing, organizing, storing, securing, preserving, retrieving and disseminating relevant information resources

Kinengyere, (2007) stated that the availability of information does not necessarily mean actual use because the users may not be aware of the availability of such resources, they do not know how to access these resources, or do not know what the resources offer. Thus, the electronic information resources should to be properly managed so as to satisfy the needs of users and to make accessible to users as target customers. And also human errors could be seen as a factor which affects the management of electronic information resources. Always what (data or information) has been inputted in to a machine or computer is what to be accessed, so staff should be cautious about information in their work in order to avoid errors.

There is a need for university library to trained their staffs on technical knowhow on managing the e resources either in house or seminar/ Conferences and workshop and engaged the staff when automating and installation of new technology in the library to fully archive the objectives of subscription of the e resources

The researcher observed that no literature determine the access and management of the e- resources, strategies and challenges associated with management of e resources in Umaru Musa Yar'adua University Library

\section{Problem of ICT Related Facilities in the Management of Electronic Information Resources}

For the management of electronic information resources in any given library, academic libraries in particular, there is need a lots of information and communication technology (ICTs facilities) and these include; internet connectivity, electricity power supply, computers, scanners, air 
conditioners, storage devices, printers, programs or applications. These facilities fail to work effectively sometimes and as a result, libraries face difficulties in managing its information resources and services. This work is therefore an attempt to address this issue, and is intended to examine the problems encountered in managing electronic information resources in Umaru Musa Yar'Adua University Katsina.

Ijeoma, (2006) has the opinions inadequate ICTs facilities erratic power supply in-depth ICT skills and information searching skills among library staff, and cost of using the cybercafé are barriers to the use of electronic resources; inadequate resources like computers, and poor internet connectivity, inappropriate usage and lack of appropriate skills among users also affects the management of electronic information resources in libraries.

\section{Population}

The population of the study consist all the forty two (42) library staff in Umaru Musa Yar'adua University Library Katsina State, Nigeria

Table 1. Population of the Study

\begin{tabular}{|l|l|l|l|}
\hline $\mathbf{S} / \mathbf{N}$ & Respondents based on professions & Population & Percentage \\
\hline $\mathbf{1}$ & Professional staff & 10 & 23.8 \\
\hline $\mathbf{2}$ & Para professional staff & 19 & 45.2 \\
\hline $\mathbf{3}$ & Nonprofessional staff & 13 & 31.0 \\
\hline $\mathbf{4}$ & Total & 42 & $100 \%$ \\
\hline
\end{tabular}

Table 2. Professionalism LRCN BENCH MARK

\begin{tabular}{|l|l|l|l|}
\hline $\mathbf{S} / \mathbf{N}$ & Respondents based on professions & Frequency & Percentage \\
\hline $\mathbf{1}$ & Professional staff & 8 & $20.5 \%$ \\
\hline $\mathbf{2}$ & Para professional staff & 19 & $48.7 \%$ \\
\hline $\mathbf{3}$ & Nonprofessional staff & 12 & $30.8 \%$ \\
\hline $\mathbf{4}$ & Total & 39 & $100 \%$ \\
\hline
\end{tabular}

Table 2 presents the profession of the respondents whereby Para professional staff have the highest number of nineteen $19(48.7 \%)$ respondents, followed by Non Professional staff with twelve (12) respondents which represents $30.8 \%$ and then lastly the professional staff with only eight (8) respondents which stands for $20.5 \%$.

\subsubsection{Respondents by Qualification}

The following table presents the respondents according to their educational qualification as workers of the UMYUK Library.

Table 3. Qualification

\begin{tabular}{|l|l|l|l|}
\hline S/N & Qualification & Frequency & Percentage \\
\hline 1 & PhD & - & - \\
\hline 2 & MLS/MIS & 5 & $12.8 \%$ \\
\hline 3 & BLIS & 3 & $7.7 \%$ \\
\hline 4 & ND/ALO & 19 & $48.7 \%$ \\
\hline 5 & SSCE & 12 & $30.8 \%$ \\
\hline 6 & Total & 39 & $100 \%$ \\
\hline
\end{tabular}

Table 3 shows that majority of the respondents have National diploma in library and information science with 19 members which is $(48.7 \%)$ followed by those with Senior secondary school certificate twelve (12) in number which stands for $(30.8 \%)$ and then those with masters degrees who are five (5) in number which represents $(12.8 \%)$ followed by those with first degrees who are three (3) that is $(7.7 \%$ ) and are the least in terms of educational qualification among the library staff of UMYUK Library.

Table 4. Working Experience

\begin{tabular}{|l|l|l|l|}
\hline S/N & Working experience & Frequency & Percentage \\
\hline 1 & $1-2$ years & 3 & $7.7 \%$ \\
\hline 2 & $3-4$ years & 4 & $10.3 \%$ \\
\hline 3 & $5-6$ years & 13 & $33.3 \%$ \\
\hline
\end{tabular}




\begin{tabular}{|l|l|l|l|}
\hline 4 & $7-8$ years & 9 & $23.1 \%$ \\
\hline 5 & Above 8 years & 10 & $25.6 \%$ \\
\hline 6 & Total & 39 & $100 \%$ \\
\hline
\end{tabular}

Table 4 shows that, in terms of working experience, those staff with 5-6 years working experience are the highest with 13 members that presents $(33.3 \%)$ followed by those respondents with above 8 years working experience that are 10 in number and stands for $(25.6 \%)$ then those with 7-8 years who are 9 that is $(23.1 \%)$ followed by those with 3-4 years who are 4 which presents (10.3\%) and lastly those with 1-2 years working experience who are $3(7.7 \%$.). These categories of staffs are responsible for day to day running activities of the library.

Table 5. Types of Electronic Information Resources in UMYUK Library

\begin{tabular}{|l|l|l|l|l|l|}
\hline S/N & Variables & Frequency (Yes) & Percentage & Frequency (No) & Percentage \\
\hline 1 & E-books & 29 & $74.4 \%$ & 10 & $25.6 \%$ \\
\hline 2 & E-journals & 35 & $89.7 \%$ & 4 & $10.3 \%$ \\
\hline 3 & Internet & 39 & $100 \%$ & & - \\
\hline 4 & CDs/DVDs & 27 & $69.2 \%$ & 12 & $30.8 \%$ \\
\hline 5 & Audiovisual & 5 & $12.8 \%$ & 34 & $87.2 \%$ \\
\hline 6 & Databases & 39 & $100 \%$ & - & - \\
\hline
\end{tabular}

Table 5 indicates that, internet and databases are the highest electronic information resources in UMYUK Library with 39 (100\%) respondents each, followed by e-journals with 35 respondents that stand for (89.7\%) then e-books with 29 respondents that represents (74.4\%) CDs/DVDs are the next with 27 respondents which is $(69.2 \%)$ and then lastly audiovisual resources with only 5 respondents which is $(12.8 \%)$.

Table 6. Strategies for the Enhancement of the Management of E-Resources

\begin{tabular}{|l|l|l|l|l|l|}
\hline S/N & Variables & Frequency (Yes) & Percentage & Frequency (No) & Percentage \\
\hline $\mathbf{1}$ & OPAC & 39 & $100 \%$ & - & - \\
\hline $\mathbf{2}$ & Library automation & 20 & $51.3 \%$ & 19 & $48.7 \%$ \\
\hline $\mathbf{3}$ & Information literacy & 12 & $30.8 \%$ & 27 & $69.2 \%$ \\
\hline $\mathbf{4}$ & Integration settings & 15 & $38.5 \%$ & 24 & $61.5 \%$ \\
\hline $\mathbf{5}$ & Consortium & - & - & - & - \\
\hline
\end{tabular}

Table 6 indicated that, online public access catalogue (OPAC) is the major strategy used for the enhancement of the management of electronic information resources in UMYUK Library with $39(100 \%)$ respondents, followed by library automation with $20(51.3 \%)$ respondents, followed by integration settings with 15 respondents that is (38.5\%) and then lastly information literacy that has 12 respondents which stands for $(30.8 \%)$ respectively. These strategies are used in order to provide accurate and relevant services to the library users for them to be satisfied.

Table 7. Staff Related Challenges in the Management

\begin{tabular}{|l|l|l|l|l|l|}
\hline S/N & Variables & Frequency (Yes) & Percentage & Frequency (No) & Percentage \\
\hline $\mathbf{1}$ & Inadequate qualified staff & 24 & $61.5 \%$ & 15 & $38.5 \%$ \\
\hline $\mathbf{2}$ & Negligence of the staff/ staff errors & 15 & $38.5 \%$ & 24 & $61.5 \%$ \\
\hline $\mathbf{3}$ & Lack of information retrieval skills by the staff & 19 & $48.7 \%$ & 20 & $51.3 \%$ \\
\hline $\mathbf{4}$ & Poor technical support by the staff & 23 & $59.0 \%$ & 16 & $41.0 \%$ \\
\hline $\mathbf{5}$ & Lack of IT skills by the staff & 14 & $35.9 \%$ & 25 & $64.1 \%$ \\
\hline
\end{tabular}

Table 7 indicates that, the highest challenge with regard to staff in the management of electronic information resources in UMYUK Library is inadequate of staff with 24 (61.5\%) respondents, followed by poor technical support by the staff with $23(59.0 \%)$ respondents and then lack of information retrieval skills by the staff with 19 (48.7) respondents, followed by negligence of staff or staff errors with 15 (38.5\%) respondents and then lastly inadequate skills of information and communication technology by the staff with 14 (35.9\%) respondents. 
Table 8. ICT Related Problems that Affects the Management of E- Resources

\begin{tabular}{|l|l|l|l|l|l|}
\hline S/N & Variables & Frequency (Yes) & Percentage & Frequency (No) & Percentage \\
\hline 1 & Power failure & 26 & $66.7 \%$ & 13 & $33.3 \%$ \\
\hline 2 & $\begin{array}{l}\text { Inadequate ICT } \\
\text { facilities }\end{array}$ & 24 & $61.5 \%$ & 15 & $38.5 \%$ \\
\hline 3 & Poor network & 28 & $71.8 \%$ & 11 & $28.2 \%$ \\
\hline 4 & Poor storage media & 21 & $53.8 \%$ & 18 & $46.2 \%$ \\
\hline 5 & $\begin{array}{l}\text { Obsolescence of } \\
\text { software }\end{array}$ & $48.7 \%$ & 20 & $51.3 \%$ \\
\hline
\end{tabular}

Table 8 shows the challenges faced by the UMYUK Library that are related to ICT facilities in the management of electronic information resources whereby the highest challenge is poor network with 28 respondents which is equivalent to $(71.8 \%)$ followed by power failure with 26 respondents that stands for $(66.7 \%)$ then inadequate ICT facilities that were suggested by 24 respondents $(61.5 \%)$ and then poor storage media with $21(53.8 \%)$ respondents and lastly obsolescence of software which has 19 (48.7\%) respondents respectively. Thus, these are problems that affect the library in the management of electronic information resources.

Table 9. Solutions to the Above Identified Challenges.

\begin{tabular}{|l|l|l|l|l|l|}
\hline S/N & Variables & Frequency (Yes) & Percentage & Frequency (No) & Percentage \\
\hline $\mathbf{1}$ & Provision of adequate power & 26 & $66.7 \%$ & 13 & $33.3 \%$ \\
\hline $\mathbf{2}$ & $\begin{array}{l}\text { Provision of adequate ICT } \\
\text { facilities }\end{array}$ & 24 & $61.5 \%$ & 15 & $38.5 \%$ \\
\hline $\mathbf{3}$ & Provision of good network & 28 & $71.8 \%$ & 11 & $28.2 \%$ \\
\hline $\mathbf{4}$ & Provision of good storage media & 21 & $53.8 \%$ & 18 & $46.2 \%$ \\
\hline $\mathbf{5}$ & Provision of up to date software & 19 & $48.7 \%$ & 20 & $51.3 \%$ \\
\hline $\mathbf{6}$ & Recruiting qualified staff & 24 & $61.5 \%$ & 15 & $38.5 \%$ \\
\hline $\mathbf{7}$ & Staff training and development & 30 & $76.9 \%$ & 9 & $23.1 \%$ \\
\hline
\end{tabular}

Table 9 indicates ways of tackling the challenges as the highest among the variables is the issue of staff training and development with 30 (76.9\%) respondents, followed by provision of good network with $28(71.8 \%)$ respondents and then provision of adequate power supply with 26 (66.7\%) respondents followed by provision of adequate information and communication technology facilities and that of recruiting qualified staff that will manage the resources with $24(61.5 \%)$ respondents each, the next is the provision of good storage media whose respondents were 21 (53.8\%) and finally, the provision of up to date library automation software that can be used to successfully manage these electronic information resources with 19 (48.7\%) respondents.

\section{Findings and Recommendations}

The strategies adopted by the library for the enhancement of the management of electronic information resources are library automation by using KOHA on online public access catalogue

Information and communication technology related problems that affect the management of electronic information resources in Umaru Musa Yar'Adua university Katsina library are poor network provision and erratic power supply, inadequate qualified staff, technical support by the staff are the major problems in the management of electronic information resources proper.

The university library should provide network connectivity as well as an alternative power supply, recruiting qualified staff, proper staff training and development to improve the management of electronic information resources so as to satisfy the needs of library patrons as target customers of the library.

There should be a policy as well as a strategic plan for ICT infrastructural development in the university library. This will provide an enabling environment for the organization and use of EIRS in the university Library and Digitization projects needs to be developed in the University library. These include integrated library automation, creation of standardized databases, digitization of theses and dissertations. Commitments to each of these projects will redefine and reinvent the university library for user-centered services.

User orientation programme should be improved in the university library so that the university community both staffs and students can access and make use of electronic information resources. 


\section{CONCLUSION}

In the $21^{\text {st }}$ century is not a matter of how many volumes of books you have in the library but how many databases subscribed in the library therefore, the library are advised to keep pace with changes otherwise they will be left behind. Providing unlimited access to electronic information resources in the university library as well as keeping track of them is one way of keeping pace with change. The success of the university library in electronic resources provision depends on its ability to contend with the problems associated with the management of these e-resources. These problems are found to be linked with administrative policies or practices, staffing and e-resources provision using ICT; consequently the library management of this institution (UMYUK) should therefore try its possible best to see that, these electronic information resources are managed accordingly in order to ensure proper utilization by the university community to satisfy their needs as target customers of the library.

\section{REFERENCES}

1. Adegbore, A. M., Okwilagwe, O. A., \& Salaam, M. O. (2013). Management of electronic resources in Private Universities in South-West Nigeria. Elixir International Journal , 14590-14594.

2. Akinsola, M., Tella, A., \& Tella, A. (2007). Correlates of Academic Procrastination and Mathematics Achievement of University Undergraduate Students. Eurasia Journal of Mathematics, Science \& Technology Education, 363-370.

3. Ani, O., \& Blessing, A. (2008). Towards effective development of electronic information resources in Nigerian university libraries. Emerald Group Publishing Limited , 504-514.

4. Breivold, S. (2009). Electronic Resource Management in Libraries: Research and Practice. Electronic journal , 1-9.

5. Gbaje, E. S. (2012). Digital preservation policy in National Information Centres in Nigeria. Emerald Group Publishing Limited, 483-492.

6. Ijeoma, I. (2006). Access to Electronic Healthcare Information Resources in Developing Countries: Experiences from the Medical Library, College of Medicine, University of Nigeria. IFLA Journal, 5461.

7. Jeyapragash, A.Muthuraj, A., \& Rajkumar, T. (2017). Electronic Resource Management Tools: with Special Reference to Open Source Software. Tiruchirappalli: unpublished.

8. Kinengyere, A. (2007). The effect of information literacy on the utilization of electronic information resources in selected academic and research institutions in Uganda. electronic journal , 1-13.
9. Okiki, O. C., \& Asiru, S. M. (2011). Use of Electronic Information Sources by Postgraduate Students in Nigeria: Influencing Factors. Library Philosophy and Practice, 1-10.

10. Okoye, M. O., \& Ezeani, C. N. (2009). Introduction to the Use of Library and Study Skills, Chapter: 7. (pp. 105-117). Awemark: Awemark Publishers.

11. Shuling, W. (2007). Investigation and analysis of current use of electronic resources in university libraries. Emerald Group Publishing Limited, 7288.

12. Thanuskodi, S. (2009). Use of Internet and electronic resources for medical science information: A case study. Journal of Communication, 27-44. 